\title{
Influencing adaptation processes on the Australian rangelands for social and ecological resilience
}

\author{
Nadine A. Marshall ${ }^{1,2}$ and Chris J. Stokes ${ }^{1}$
}

\begin{abstract}
Resource users require the capacity to cope and adapt to climate changes affecting resource condition if they, and their industries, are to remain viable. Understanding individual-scale responses to a changing climate will be an important component of designing well-targeted, broad-scale strategies and policies. Because of the interdependencies between people and ecosystems, understanding and supporting resilience of resource-dependent people may be as important an aspect of effective resource management as managing the resilience of ecological components. We refer to the northern Australian rangelands as an example of a system that is particularly vulnerable to the impacts of climate change and look for ways to enhance the resilience of the system. Vulnerability of the social system comprises elements of adaptive capacity and sensitivity to change (resource dependency) as well as exposure, which is not examined here. We assessed the adaptive capacity of 240 cattle producers, using four established dimensions, and investigated the association between adaptive capacity and climate sensitivity (or resource dependency) as measured through 14 established dimensions. We found that occupational identity, employability, networks, strategic approach, environmental awareness, dynamic resource use, and use of technology were all positively correlated with at least one dimension of adaptive capacity and that place attachment was negatively correlated with adaptive capacity. These results suggest that adaptation processes could be influenced by focusing on adaptive capacity and these aspects of climate sensitivity. Managing the resilience of individuals is critical to processes of adaptation at higher levels and needs greater attention if adaptation processes are to be shaped and influenced.
\end{abstract}

Key Words: adaptive capacity; livestock industry; networks; primary resource industry; resource dependency; social resilience; vulnerability

\section{INTRODUCTION}

Managing the climate and its impacts on natural resources is not a new challenge. Ever since the inception of agriculture some 4-10,000 years ago, human civilizations have had to contend with "good" years and "bad" years (Riebsame 1988). In addition to other more recent economic, social, and environmental demands humans must now also contend with climate change in which rainfall patterns and mean temperatures in particular are likely to be significantly altered (Howden et al. 2007, Stafford Smith et al. 2007, Howden and Stokes 2010, Quinn et al. 2011).

Climate change is expected to bring with it change events that are unprecedented in human history (Smithers and Smit 1997, IPCC 2007). It acts to push natural resource systems, and those dependent on them, toward their thresholds of tolerance, testing whether they can absorb the impacts and adapt (Marshall et al. 2012). For example, climate models indicate that by 2030 resourcedependent industries in regions such as northern Australia will most likely experience more droughts and lower summer rainfall than ever before (Cobon et al. 2009). However, to meet the demands of an ever-increasing human population, the industries and enterprises in these regions must enhance their productivity without compromising their capacity to be productive in the future. Resource users will have to develop the capacity to cope and adapt to these changes if they, and the communities dependent on them, are to be sustained (Marshall 2010).

Sustaining natural resources is paramount for adapting to climate change. However, we argue that this goal can only be achieved if people have the capacity to sustain natural resources and are resilient to changes in resource condition. Social and ecological systems are intrinsically interdependent: the future of one depends on the other and loss of social resilience has been linked to loss of ecological resilience and vice versa (Levin et al. 1998, Ostry 1999). Resource-dependent communities and industries that have low resilience are unlikely to contribute to the resilience of natural resources but rather to their demise through seeking to bolster social well-being in the short term (Levin et al. 1998, Ostry 1999). Climate change thus threatens natural resources not only through negative impacts of changing rainfall patterns and temperatures that can have far-reaching impacts on human societies, but also through eroding social resilience, which in turn, has the potential to further amplify environmental degradation (Marshall et al. 2013).

Given the link between social and ecological systems, maintaining social resilience through supporting adaptation processes is likely to be an essential strategy for adapting to climate change (Cinner et al. 2012). Social systems require a healthy capacity to cope and adapt to the changes in the resource so as to minimize the threat of overharvesting and loss of environmental stewardship. However, human communities have frequently been expected to adapt to reductions in ecosystem goods and services, with little attention focused on whether they have the capacity to do so. This has often pushed communities to either accept a decline in their livelihoods and reduce well-being or to compensate through further, or even illegal, exploitation of natural resources (Marshall et al. 2012). Under the growing threat of climate change, and because of the interdependencies between people and ecosystems, understanding and supporting resilience of resourcedependent people may be as important an aspect of effective resource management as managing the resilience of ecological components.

Resilience represents a property that sustains social and ecological systems. It is the capacity of either system to absorb change and 
reorganize so as to retain essentially the same function, structure, identity, and feedbacks. Resilient systems are able to undergo change, such as resource extraction, and adapt, up until their thresholds of coping are reached. If thresholds are crossed, resource systems are apt to lose resilience and collapse (Walker et al. 2006). Sustaining natural resources and the societies dependent on them might thus be possible through the maintenance of properties that can confer resilience (Gunderson 1999, Kates et al. 2000, Gunderson et al. 2002, Walker et al. 2002). Properties typically associated with resilience include possessing creativity and innovation, for identifying solutions or adaptation options (Carpenter et al. 2001); testing and experimenting with options (Olsson et al. 2004); recognizing and responding to effective feedback mechanisms (Dessai and Hulme 2007); employing adaptive management approaches (Gunderson and Holling 2002); possessing flexibility (Gunderson 1999); being able to reorganize given novel information (Pelling 2007); managing risk (Tompkins et al. 2008); and having necessary resources at hand (Cinner et al. 2009). These characteristics are necessary across global, national, regional, local, and individual scales.

We concentrate on influencing adaptation processes at the individual scale because this scale is often overlooked in the development of regional policies, and because the individual scale is necessary to complement research at other scales. The capacity of farmers, fishers, foresters, and producers to adopt best practices and adapt to the changing environment may be vital to the success of their respective industries. For example, in many situations a critical mass of individuals may be needed if an industry-led strategy is to be supported (Marshall et al. 2011, Taljaard et al. 2011, Shirk et al. 2012). However, not all individuals will have the same capacity to cope and adapt; some will face considerable barriers that make embarking on a new approach too challenging (Berkhoff and Herrmann 2009, Cinner et al. 2011, Marshall 2011). We argue that by understanding and targeting adaptation responses at the individual scale, broad scale policies and strategies are more likely to be effectively designed and implemented (Cumming et al. 2006).

The focus of this paper was to examine how climate adaptation processes in resource users living and working in a climate sensitive industry within Australia might be influenced. Specifically, we examine the adaptive capacity of resource users, and their association with climate sensitivity or "resource dependency" (for the purposes of this study we see climate sensitivity and resource dependency as effectively interchangeable; see Marshall 2011). Other studies have looked at the influence of resource dependency on the commercial fishing industry (Marshall et al. 2007), peanut industry (Marshall et al. 2012), and cattle grazing (Marshall 2010) and have found that several important components of resource dependency can be associated with adaptive capacity given certain contexts. However, to date, there is little knowledge of how individual, isolated studies can contribute to consolidated or generic lessons. In this study we attempt to address the extent to which empirical knowledge might be developed about the relationship between adaptive capacity and resource dependency and the extent to which context is important.

Resource dependency is a measure of the strength of the relationship between resource users and a climate-sensitive natural resource. The more dependent people are on a natural resource, the more sensitive they are to change (Bailey and Pomeroy 1996). Resource dependency has been conceptualized as comprising at least the following dimensions: occupational identity, place attachment, employability, networks, dependents, business approach, income, financial buffer, local knowledge, environmental awareness, resource use, and use of technology (Marshall 2011).

We refer to the northern Australian rangelands as an example of a system that is particularly vulnerable to the impacts of climate change (Mekbeb et al. 2009, Crimp et al. 2010, Dougill et al. 2010) and look for ways to enhance its resilience through building the adaptive capacity of cattle producers (resource users). Adaptive capacity has been operationalized at the household (Cinner and Bodin 2010), community (Smit and Wandel 2006, Cinner et al. 2012), and regional scales (Brooks and Adger 2004). At the individual scale, adaptive capacity has been operationalized according to four measurable attributes reflecting an individual's skills, circumstances, perceptions, and willingness to change (Marshall and Marshall 2007). Marshall and Marshall's (2007) dimensions of adaptive capacity, first presented in this journal and used elsewhere (Marshall 2010, Sutton and Tobin 2012) were based on survey responses to generic change statements where responses were clustered into four relatively independent components (using a Principal Components Analysis); (1) how risk and uncertainty are managed, (2) the extent of skills in planning, experimenting, learning, and reorganizing, (3) the level of financial and psychological flexibility to undertake change; and (4) the anticipation of the need and willingness to contemplate and undertake change. These dimensions closely resemble factors that confer resilience at other scales (Gunderson and Holling 2002). We use these dimensions as the basis from which to examine the capacity to undertake change related to climate change and how this capacity might be influenced by a range of factors.

Rangelands represent some $70 \%$ of the Australian landmass and $33 \%$ of the world's terrestrial landscapes including some of the poorest communities in the world (Stafford Smith 2008). Extensive grazing lands typically have low and variable productivity, and as such are particularly vulnerable to unsustainable resource management (Thomas 2008). Producers must contend with seasonal variability and an already harsh environment (Walker and Janssen 2002, McAllister et al. 2006, Cooper et al. 2008, Hobbs et al. 2008). The added challenge of climate change requires producers to make appropriate management decisions in the face of uncertainty and especially in the face of surprises. Success not only depends on maximizing productivity during any one season, but also on minimizing impact on the future ability of the land to produce (McKeon et al. 2000, Anderies et al. 2002). Of particular concern is that degradation processes on the rangelands are especially accelerated during drought periods (Howden et al. 2007, Briske et al. 2010). Knowing when to alter stocking rates, when to supplement feeding, when to agist (moving livestock to other properties), when to burn, and when to alter water supplies, for example, can differentiate between those producers (and regions) likely to be successful in the long term and those that are not (Hansen 2002). If stocking rates are too high at the onset of drought, for example, soil sustainability will be diminished and 
Table 1. Level of adaptive capacity within the cattle industry of northern Australia.

\begin{tabular}{|c|c|c|c|}
\hline Dimensions & Survey statement & $\%$ Strongly agree & $\%$ Agree \& strongly agree \\
\hline \multirow{4}{*}{$\begin{array}{l}\text { One: Perceptions of } \\
\text { risk and managing } \\
\text { uncertainty }\end{array}$} & $\begin{array}{l}\text { The important thing for me is to minimise my losses } \\
\text { during bad seasons }\end{array}$ & $41.8 \%$ & $92.0 \%$ \\
\hline & $\begin{array}{l}\text { Even if I knew drought was likely to occur, there is not } \\
\text { much I could do about it }\end{array}$ & $16.0 \%$ & $26.4 \%$ \\
\hline & $\begin{array}{l}\text { I believe that opportunity comes } \\
\text { from taking calculated risks }\end{array}$ & 42.2 & 82.3 \\
\hline & $\begin{array}{l}\text { I always assume the worst when I make land } \\
\text { management decisions }\end{array}$ & 28.4 & 49.5 \\
\hline \multirow{4}{*}{$\begin{array}{l}\text { Two: Planning, } \\
\text { learning, strategic } \\
\text { skills }\end{array}$} & I have always grazed cattle in (generally) the same way & $25.0 \%$ & $42.3 \%$ \\
\hline & $\begin{array}{l}\text { I don't really believe in long-term } \\
\text { planning - things are too uncertain }\end{array}$ & $19.1 \%$ & $32.7 \%$ \\
\hline & $\begin{array}{l}\text { I like to experiment with new ways to } \\
\text { graze cattle }\end{array}$ & $37.0 \%$ & $67.1 \%$ \\
\hline & $\begin{array}{l}\text { I am prepared to take advantage of a } \\
\text { particularly good season }\end{array}$ & $38.5 \%$ & $85.0 \%$ \\
\hline \multirow[t]{2}{*}{ Three: Flexibility } & $\begin{array}{l}\text { I am less likely to survive drought compared to other } \\
\text { cattle producers I know }\end{array}$ & $8.4 \%$ & $12.1 \%$ \\
\hline & $\begin{array}{l}\text { Regardless of what happens, we have made sure that we } \\
\text { are financially secure }\end{array}$ & $40.9 \%$ & $61.1 \%$ \\
\hline \multirow[t]{3}{*}{$\begin{array}{l}\text { Four: Interest in } \\
\text { change }\end{array}$} & $\begin{array}{l}\text { I already access scientific technology and expertise } \\
\text { relating to the climate }\end{array}$ & $43.4 \%$ & $61.5 \%$ \\
\hline & $\begin{array}{l}\text { If needed, I am prepared to completely change the way I } \\
\text { manage my property in order to survive as a producer }\end{array}$ & $41.3 \%$ & $63.8 \%$ \\
\hline & $\begin{array}{l}\text { I would like more access to climate technology \& } \\
\text { expertise }\end{array}$ & $38.3 \%$ & $55.0 \%$ \\
\hline
\end{tabular}

the productivity of future years will be impacted (McKeon et al. 2004, Keogh et al. 2006). Producers, like any resource user, that can anticipate or effectively react to climate events and climate extremes are more likely to adapt to new climate conditions and be successful (Reed et al. 2007, Park et al. 2012).

\section{METHODS}

\section{Survey development}

Survey questions were developed so as to quantify a producer's climate sensitivity and capacity to adapt (Marshall et al. 2007, Marshall and Marshall 2007). Demographic questions within the survey, such as "In what year were you born?" required simple answers. Some questions such as, "Are you employed as a land manager on someone else's land?" required binary responses (a "yes" or "no" answer). Answers to most questions, however, were expressed as a statement and reflected an attitude, opinion, or stance. For example, one statement was, "I have always grazed cattle in (generally) the same way." Respondents were asked to rate how strongly they agreed with each statement using a 5-point rating scale $(1=$ strongly disagree, $2=$ disagree, $3=$ neutral, $4=$ agree, $5=$ strongly agree, scaled response; Tables 1 and 2). This scale builds upon the Likert scale (Likert 1932) and is especially useful in quantifying and comparing attitudes because results can be standardized and contrasted. Respondents were asked to leave a question blank if they preferred. Dynamic resource use was assessed as the difference between the minimum and maximum head of cattle stocked in the previous 10 years. Responses for negative statements were reversed prior to analysis. An initial version of the survey was pilot-tested with 10 producers in their homes to ensure that the questions were readable and unambiguous. A final copy of the survey may be obtained from contacting the primary author.

\section{Survey administration}

An intensive media campaign commenced the survey administration phase to introduce the research to producers across northern Australia. Producers also received a personal letter informing them of the research and inviting them to participate. Names, addresses, and telephone numbers of producers were obtained from the yellow pages, an online business directory. Within two to three weeks of receiving the letter, producers received a telephone call and were again invited to participate in the research over the telephone. We asked to speak with the "decision makers." Some were happy to complete the survey immediately, and others made an appointment at a more convenient time. Of the producers that were contacted, 32 declined from participating in the research. Our sample of 240 producers represents $78 \%$ of those contacted.

\section{Data analyses}

Descriptive statistics were used to present the adaptive capacity and level of climate sensitivity (resource dependency) of 
producers. The components of resource dependency and the four components of adaptive capacity were assessed for each cattle producer by calculating an F-score or "weighted mean" for their set of responses to relevant statements in SPSS ${ }^{\circ}$. Correlations between the F-scores for adaptive capacity and resource dependency were analyzed using Pearson correlation matrices.

\section{RESULTS}

The adaptive capacity of producers, according to their responses to statements about their perceptions of risk, strategic skills, flexibility, and interest is presented in Table 1. There was much variability in responses to statements about adaptive capacity, but in general cattle producers were more likely to be adaptive in terms of: their ability to minimize losses during bad seasons and seeing opportunity from taking calculated risks (dimension one); experimenting with new ways to graze cattle and taking advantage of a particularly good season (dimension two); being financially secure, regardless of what happens (dimension three), and; being prepared to completely change the way they manage their property to survive as a producer (dimension four).

The level of climate sensitivity (resource dependency) of producers, according to their responses to statements about their occupational identity, place attachment, employability, networks, dependents, business approach, income, financial buffer, local knowledge, environmental awareness, resource use, and use of technology is presented in Table 2. Results suggest that cattle producers across northern Australia are potentially sensitive to changes affecting their relationship with the natural resource because: they have a very strong identity in that they love being a producer (93\%); their occupation represents a lifestyle (80\%); they have operated as a producer for a very long time (mean 37 years and a mean of 3 generations). Producers are also sensitive to change because: around half do not perceive that they have many options available to them other than being a producer (47\%); they are unlikely to discuss approaches for climate adaptation with other cattle producers $(48 \%)$ or government agencies and researchers (22\%); less than half have a documented business plan (46\%); most producers do not definitely have a strong financial buffer in case of emergencies; and around half of producers $(45 \%)$ suggest that they cannot manage their land condition because (their) land condition is not related to the way (they) use the land but rather to the local environment, climate, and geology.

The strength of association between dimensions of adaptive capacity and resource dependency is presented in Table 3. The components of resource dependency that are positively associated with adaptive capacity include a stronger occupational identity, stronger place attachment, higher employability, more effective networks, a higher strategic approach, higher environmental awareness, dynamic use of the resource, and use of technology.

\section{DISCUSSION}

Our study provides practical knowledge of individual adaptive capacity that, in concert with other studies, can inform climate adaptation planning in agricultural regions around the world. Our results confirm existing knowledge that the adaptive capacity of producers in northern Australia is highly variable, where some individuals display high levels of adaptive capacity across several dimensions (such as the ability to minimize losses during bad seasons, take advantage of a particularly good season, being financially secure or prepared to completely change the way they manage their property to survive as a producer) while others show relatively low levels on these dimensions (Table 1; Marshall and Smajgl 2013). Producers were also variably sensitive to climate change. Many cattle producers were dependent on their occupation because of their occupational identity; the employment it provided, in that they were unlikely to gain employment elsewhere because of their age, education, and attitude to working elsewhere; lack of effective networks; lack of a strategic business approach; and restrictive perceptions of land management. However, many producers were not dependent on their occupation for these reasons (Table 2).

Our aim was to uncover any association between climate sensitivity and adaptive capacity in cattle producers for the purposes of examining whether adaptive capacity might be influenced, and to then use these lessons to develop more generic knowledge about the interaction between resource dependency and adaptive capacity across agricultural contexts. We found that several dimensions of climate sensitivity (resource dependency) were positively associated with adaptive capacity. Although we do not attribute causality, the associations suggest that investing in certain aspects of resource dependency may influence adaptive capacity and the processes of adaptation on the rangelands. The challenge is to understand the nature of the relationship between adaptive capacity and resource dependency and recognize when resource dependent factors act to enhance adaptive capacity and when they act as barriers to change.

\section{Attachment to occupation (occupational identity)}

We found a strong and significant relationship between two dimensions of adaptive capacity, i.e., risk and planning, and occupational identity. These results confirm existing knowledge that resource users such as producers, farmers, or fishers can be sensitive to change because of their attachment to their occupation. Occupational attachment may act to influence adaptive capacity through providing a strong motivation to continue within their chosen occupation. The risks associated with change appear to be more positively perceived as do the level of skills and experience to cope and adapt to change. However, other studies suggest that occupational attachment can also act as a barrier to change. When a person with a strong occupational attachment is suddenly faced with the prospect that they are no longer able to continue in their current occupation, or are challenged with what it means to be a producer, they may lose an important part of their identity and will erect barriers to change to protect their identity (Carroll and Lee 1990, Claudet et al. 2006).

\section{Employability}

We found, like others, that employability was positively and significantly associated with adaptive capacity suggesting that people who are younger, have transferrable skill sets, and/or have a positive attitude to working elsewhere are more likely to have the capacity to cope and adapt to change (Barnes et al. 1999, Marshall and Marshall 2007, Marshall et al. 2013). People living and working in resource dependent communities often have limited experience in other occupations. As a result, they often lack transferable skills and consequently become locked into their occupation. Our results confirm that people who are older, have 
Table 2. Level of resource dependency within the cattle industry of northern Australia.

\begin{tabular}{|c|c|c|c|}
\hline $\begin{array}{l}\text { Factors of resource } \\
\text { dependency }\end{array}$ & Survey statement & $\begin{array}{l}\% \text { Strongly agree Or } \\
\text { Response }\end{array}$ & $\begin{array}{l}\% \text { Agree \& strongly } \\
\text { agree }\end{array}$ \\
\hline \multirow[t]{6}{*}{$\overline{\text { Identity }}$} & I love being a cattle producer & $62.4 \%$ & $92.6 \%$ \\
\hline & Being a producer is a lifestyle - it is not just my job & $51.9 \%$ & $80.5 \%$ \\
\hline & $\begin{array}{l}\text { I would happily consider another occupation if the need } \\
\text { arose }\end{array}$ & $25.9 \%$ & $39.1 \%$ \\
\hline & How long have you been grazing cattle (years)? & \multicolumn{2}{|c|}{ Mean $=36.76, \mathrm{SE}=1.17$} \\
\hline & $\begin{array}{l}\text { How many generations of your family have worked as } \\
\text { producers? }\end{array}$ & \multicolumn{2}{|c|}{ Mean $=3.26, \mathrm{SE}=0.09$} \\
\hline & How many of your family members are cattle producers? & \multicolumn{2}{|c|}{ Mean $=3.28 \mathrm{SE}=0.28$} \\
\hline \multirow[t]{3}{*}{ Place attachment } & I would never want to move from this region & $29.4 \%$ & $54.6 \%$ \\
\hline & $\begin{array}{l}\text { I am unlikely to move elsewhere to graze cattle if } \\
\text { conditions become unsuitable here }\end{array}$ & $22.6 \%$ & $40.4 \%$ \\
\hline & How long have you grazed in this region (years)? & \multicolumn{2}{|c|}{ Mean $=31.25 \mathrm{SE}=1.31$} \\
\hline \multirow[t]{4}{*}{ Employability } & $\begin{array}{l}\text { I have many options available to me other than being a } \\
\text { producer }\end{array}$ & $33.5 \%$ & $52.8 \%$ \\
\hline & $\begin{array}{l}\text { Have you ever worked outside of the grazing industry? } \\
(1=\text { yes, } 2=\text { no })\end{array}$ & \multicolumn{2}{|c|}{ Mean $=1.38 \mathrm{SE}=0.03$} \\
\hline & Do you mind telling me in what year you were you born? & \multicolumn{2}{|c|}{ Mean $=1956 \mathrm{SE}=0.91$} \\
\hline & $\begin{array}{l}\text { Have you ever completed any trade certificate or degree? } \\
(1=\text { yes, } 2=\text { no })\end{array}$ & \multicolumn{2}{|c|}{ Mean $=1.38 \mathrm{SE}=0.03$} \\
\hline \multirow[t]{3}{*}{$\begin{array}{l}\text { Strength and quality of } \\
\text { networks }\end{array}$} & $\begin{array}{l}\text { I discuss approaches for climate adaptation with other } \\
\text { cattle producers }\end{array}$ & $38.2 \%$ & $48.2 \%$ \\
\hline & $\begin{array}{l}\text { I discuss approaches for climate adaptation with } \\
\text { government agencies and researchers }\end{array}$ & $13.2 \%$ & $21.8 \%$ \\
\hline & $\begin{array}{l}\text { I have good networks to access government agencies \& } \\
\text { government assistance }\end{array}$ & $31.6 \%$ & $48.4 \%$ \\
\hline Dependents & $\begin{array}{l}\text { How many children do you have living at home? }(>2,> \\
0)\end{array}$ & $14.5 \%$ & $58.0 \%$ \\
\hline Owner/Manager & $\begin{array}{l}\text { Are you managing the property for someone else? }(1= \\
\text { yes, } 2=\text { no })\end{array}$ & \multicolumn{2}{|c|}{ Mean $=1.28 \mathrm{SE}=0.03$} \\
\hline \multirow[t]{2}{*}{ Business approach } & $\begin{array}{l}\text { I am more of a lifestyle producer and focus less on } \\
\text { making a profit }\end{array}$ & $7.6 \%$ & $19.5 \%$ \\
\hline & I have a documented business plan & $26.5 \%$ & $46.1 \%$ \\
\hline \multirow[t]{3}{*}{ Business Size } & $\begin{array}{l}\text { How many additional people are employed on your } \\
\text { property? }\end{array}$ & \multicolumn{2}{|c|}{ Mean $=3.49 \mathrm{SE}=0.67$} \\
\hline & Approximately, how many head of cattle do you run? & \multicolumn{2}{|c|}{ Mean $=6507 \mathrm{SE}=1015$} \\
\hline & How many hectares of land do you manage? & \multicolumn{2}{|c|}{ Mean $=122,017 \mathrm{SE}=28,256$} \\
\hline Financial buffer & $\begin{array}{l}\text { Would you say you have a strong financial buffer in case } \\
\text { of emergencies? }\end{array}$ & \multicolumn{2}{|c|}{ Mean $=3.08 \mathrm{SE}=0.09$} \\
\hline Income & $\begin{array}{l}\text { Approximately, how much income does your business } \\
\text { produce (turnover) each year? } \\
1=<\mathrm{A} \$ 150 \mathrm{~K}, 2=\mathrm{A} \$ 150 \mathrm{~K}-\$ 500 \mathrm{~K}, 3=\mathrm{A} \$ 500 \mathrm{~K}- \\
\$ 1 \mathrm{M}, 4=\mathrm{A} \$ 1 \mathrm{M}-\$ 5 \mathrm{M}, 5=>\mathrm{A} \$ 5 \mathrm{M}\end{array}$ & \multicolumn{2}{|c|}{ Mean $=4.35 \mathrm{SE}=0.07$} \\
\hline Income diversity & $\begin{array}{l}\text { Over the past } 5 \text { years what } \% \text { of your FAMILY income } \\
\text { came from cattle? }\end{array}$ & \multicolumn{2}{|c|}{ Mean $=\mathrm{A} \$ 122,017 \mathrm{SE}=\mathrm{A} \$ 28,256$} \\
\hline Local knowledge & $\begin{array}{l}\text { I continually record the condition of my land so that I } \\
\text { can recognise important changes }\end{array}$ & $46.1 \%$ & $77.4 \%$ \\
\hline \multirow[t]{2}{*}{$\begin{array}{l}\text { Environmental } \\
\text { Awareness }\end{array}$} & $\begin{array}{l}\text { My current land management practices will not impact } \\
\text { on my future productivity }\end{array}$ & $30.9 \%$ & $50.2 \%$ \\
\hline & $\begin{array}{l}\text { My land condition is not related to the way I use the } \\
\text { land, but rather to the local environment, climate and } \\
\text { geology }\end{array}$ & $27.5 \%$ & $45.4 \%$ \\
\hline
\end{tabular}

\footnotetext{
${ }^{\dagger} 1=$ Not at all, $2=$ a little, $3=$ depends, $4=$ possibly, $5=$ definitely

${ }^{*} 1=1-20 \%, 2=21-40 \%, 3=41-60 \%, 4=61-80 \%, 5=81-100 \%$
} 
Table 3. The relationship between resource dependency and each of the four dimensions of adaptive capacity within producers of northern Australia.

\begin{tabular}{|c|c|c|c|c|}
\hline Resource Dependency & Risk & Plan & Cope & Interest \\
\hline Identity & $0.249 * *$ & $0.286^{* *}$ & 0.108 & 0.057 \\
\hline Place & $-0.147 *$ & $-0.208 * *$ & 0.106 & $-0.304 * *$ \\
\hline Employability & -0.080 & $0.237 * *$ & 0.010 & $0.213 * *$ \\
\hline Networks & 0.066 & $0.317 * *$ & -0.008 & $0.378 * *$ \\
\hline Dependents & 0.059 & 0.017 & -0.051 & 0.105 \\
\hline Strategic approach & $0.148 *$ & $0.477 *$ & -0.023 & $0.519 * *$ \\
\hline Business size & 0.081 & 0.146 & 0.119 & 0.054 \\
\hline Financial buffer & 0.088 & 0.001 & $0.829 * *$ & -0.078 \\
\hline$\%$ Income from cattle & 0.073 & 0.024 & 0.051 & 0.059 \\
\hline Local knowledge & 0.060 & 0.123 & -0.013 & 0.111 \\
\hline Environmental awareness & $0.255^{* *}$ & $0.178 * *$ & 0.080 & $0.214^{* *}$ \\
\hline Resource use $^{\dagger}$ & $0.233 * *$ & $0.347 * *$ & 0.114 & $0.248 * *$ \\
\hline Owner/Manager & 0.018 & -0.048 & -0.046 & 0.007 \\
\hline Use of technology & 0.111 & $0.256^{* *}$ & -0.067 & $0.631 * *$ \\
\hline
\end{tabular}

$* \mathrm{p}<0.05, * * \mathrm{p}<0.01$

$\dagger$ Uses a dynamic stocking rate

few transferable skills, or are uninterested in working elsewhere are likely to be especially sensitive to change because they are ineptly equipped to take advantage of other employment opportunities (Allison and Hobbs 2004).

\section{Family}

Adaptive capacity was not significantly associated with the number of dependents in this study. Although family members may be impacted by a loss of income or livelihood (Price and Evans 2009), and although resource users with dependents may be less able to experiment with their options for the future, our study, and those of others, suggest that dependents may also act in other ways (Allison and Hobbs 2004). For example, dependents may assist resource users to cope and adapt to change either through providing a diverse household income, additional labor, and business support, or through emotional support.

\section{Attachment to place}

We found that place attachment was significantly and negatively associated with three dimensions of adaptive capacity, i.e., risk, planning, and interest, confirming that place attachment can act as a significant barrier to change (Adger et al. 2013). This concept describes the identity that people create around a place, the sense of pride associated with belonging to it, the strong friendships and networks that might exist within it and/or the connections that might exist with ancestors. Although these considerations may act to confer resilience through providing networks and support during periods of change, people will often prefer the stability associated with remaining in the one community, and this can increase their dependency on the natural resource making them sensitive to change (Lewicka 2011, Marshall et al. 2012).

\section{Business size and skills/approach}

We found that a strategic business approach was significantly and positively associated with adaptive capacity, but did not find any association between business size and adaptive capacity. Our results support the findings of others; that business owners who are more strategic in their approach to their business and driven by economic incentives to harvest the resource are more likely to have the capacity to adapt and motivate, plan, organize, and act (Bowd et al. 2012). The business skills that people possess can thus be good indicators of their competitive advantage within a resource industry and their level of transferable skills outside of the resource industry. However, the extent of business skills present within an individual is often correlated with the size of their business; larger businesses are more likely to buffer themselves from unpredictable problems such as mechanical breakdowns, difficulties with employees, and fluctuations in the weather. They can take bigger risks and with their options for the future (Allison and Hobbs 2004, Tucker et al. 2010, Marshall et al. 2013). However, we did not see evidence of this. Our results suggest that in some instances, capital investments may, in fact, limit flexibility and stifle innovation.

Financial buffer and access to credit

Our research found that producers with a buffer were significantly and positively associated with the third dimension of adaptive capacity (coping). These results suggest that a financial buffer and having access to credit can significantly influence the extent to which a resource user can effectively respond to change (Cinner et al. 2005). Resource users without this access can lack the flexibility with which to successfully absorb the costs of change and are often reluctant to take on further risks.

\section{Income diversity}

Our results did not find any significant association between income diversity and adaptive capacity. In many regions, individuals tend to diversify their income sources to spread risk, manage seasonality, increase flexibility, achieve stability, and better cope with shocks in any one system. These individuals have 
more options for responding to climate-induced changes to key resources and be less sensitive to climate changes (Penaloza Acosta et al. 2009). However, results from our study suggest that income diversity does not necessarily provide adaptive capacity (Marshall et al. 2013).

\section{Local environmental knowledge}

We did not observe any association between adaptive capacity and the extent that environmental monitoring occurs (Marshall 2010). Some individuals have invested substantially into developing local environmental knowledge and can detect subtle changes in resource condition over time. However, this investment in knowledge might mean that individuals are less likely to move and develop it again elsewhere even though they may observe environmental degradation and recognize the need for adaptation. Although this study did not observe a significant relationship between local environmental knowledge, other studies using similar metrics have been able to detect one (e.g., Marshall et al. 2014), suggesting that the metrics for, or variability within, local environmental knowledge were inadequate in this study, or that detecting such knowledge in cattle producers versus peanut producers is more difficult.

\section{Environmental awareness}

We found that cattle producers who were aware of social norms around environmental awareness had a high level of adaptive capacity on three dimensions, i.e., risk, plan, and interest. These results suggest that resource users with a strong environmental awareness might be more flexible and supportive of resourceprotection strategies because they can develop identities such as "land steward" or "best practice operator" (Joseph et al. 2008, LaFlamme 2011). These identities may make them less dependent on traditional resource management identities, and practices, and more willing to adapt to change, such as 'best' practices.

\section{Formal and informal networks}

We found a significant relationship between people who were better networked and those with a higher adaptive capacity on two dimensions, i.e., plan and interest. Networks can be formal, through legal structures and government agencies, or informal, through friends, families, and associates (Flora 1998). Individuals with stronger, more informed, and more effective networks have reciprocal connections of interactions, increased levels of trust, and access to information that are exchanged for mutual benefit (Granovetter 1973, Flora and Flora 1993, Cinner et al. 2007). Our results suggest that people who are well networked tend to have more options available to them and seem to be aware of the need to change (McAllister et al. 2005, 2006, Marshall 2011).

\section{Resource Use}

In our study we found that producers who used a flexible stocking rate (difference between the minimum and maximum head of cattle stocked in the previous 10 years), tended to be strongly and significantly associated with three dimensions of adaptive capacity, risk, plan, and interest. These results suggest that resource users who are dynamic in the way that they plan their activities are more likely to be aware of environmental feedbacks, be responsive, and have a longer term vision for their land.

\section{Use of technology}

We also found that use of technology was positively associated with two dimensions of adaptive capacity. Technology offers resource users the opportunity to make better climate-sensitive decisions and enhance resilience to climate variability (Marshall et al. 2011).

Adaptation to climate change will make a major difference to the extent of the impacts of climate change that are experienced by resource users living and working on the land. Natural resource management (NRM) organizations and other institutions charged with ensuring agricultural sustainability in Australia might attempt to accelerate efforts to prepare for those changes and moderate the impacts that are inevitable. Influencing adaptation processes on the Australian rangelands and other resource industries around the world will be about increasing the adaptive capacity of resource users. Our results, like those of others, suggest that resource users' perceptions of the risks associated with change are likely to be associated with their identity, their strategic approach, environmental awareness, and resource use. These factors could be considered in the development of strategies and policies aiming to influence adaptation processes. Although identity can be difficult to influence, the other characteristics are less so. For example, encouraging a strategic approach and environmental awareness in producers may be challenging but may result in encouraging producers to develop their adaptive capacity. Similarly, formal learning opportunities or shared/collaborative learning through facilitated networking opportunities are two ways that government and community groups, such as NRM organizations, might begin to engage with producers to improve their perceptions of the risk and to more confidently manage uncertainty within the rangelands. The strategic skill sets that producers possessed were positively associated with their identity, their strategic approach, environmental awareness, and resource use, as well as their employability, networks, and use of technology. These lessons appear to be generic across agricultural contexts, at least within Australia. Any effort to increase the level of strategy, particularly the ability to envisage likely future scenarios (both challenges and opportunities) and develop contingency plans to respond to them, within the industry may significantly assist to better prepare them and their industry for climate change. Formal and informal learning opportunities are likely to be important.

The level of financial and emotional flexibility was significantly correlated with the presence of a financial buffer. Efforts to assist graziers to understand the need for a buffer and to develop the skills to create one might be effective in influencing adaptation. For example, work by Ash et al. (2007) suggests that it might be only every eight years that grazing enterprises have the opportunity to put money aside as a buffer for future needs. This sort of knowledge may not be so widely known within the industry, and effective communication will be key to assisting producers to develop flexibility to cope and adapt to change.

Finally, we found that an interest in change was significantly and positively associated with employability (age, education, and attitude to working elsewhere), networks, strategic approach, environmental awareness, resource use, and use of technology. It might be possible to develop an interest in change through creating facilitated networking opportunities within the industry where producers are encouraged to learn, discuss strategy, technology, resource use, and environmental impacts (McPeak 2003, Gross et al. 2006). Governments, communities, and other 
institutions that support primary industries are likely to have a vital role to play in assisting resource industries to develop the capacity to undertake a range of adaptations (Marshall et al. 2010, Stokes and Howden 2010). Creating supportive policy environments to foster the development of adaptive capacity and provide well-matched incentives for effective change would be influential in a positive adaptation process (Brooks and Adger 2004, Brooks et al. 2005).

Lessons from this work can contribute to consolidated or generic lessons about the interaction between resource dependency and adaptive capacity across agricultural contexts, at least within Australia. We find that the relationship is generally similar in that there are characteristics of resource users that are typically associated with higher adaptive capacity, e.g., a strategic approach, a financial buffer, environmental awareness, use of technology, etc. However, not all resources users have invested in enhancing their adaptive capacity regardless of how seemingly apparent the results might appear. We also find differences between studies, and these differences are important to understand before adaptation processes are planned. For example, by comparing this work with that of Marshall et al. (2012), which focused on peanut farmers, we find that there is essentially not much difference between cattle graziers and peanut farmers; they are both variably resource dependent and adaptive. The differences lie mostly in the human response to the nature of the change events, where the change event ultimately determines whether resource dependency, e.g., attachment to place or occupation in these examples, acts to enhance adaptive capacity or to erode it. When the change event requires a transformational response and threatens inherent characteristics (describing resource dependency), factors such as place attachment and occupational attachment can act as barriers to change. However, when the change event requires incremental responses, as described in this study, occupational and place attachments can act to enhance adaptive capacity. This study offers useful insights into factors likely to enhance adaptive capacity, but caveats are provided suggesting that developing resilience to surprises may be more challenging, where some surprises, depending on their nature, may bring out either the best or worst in the capacity of resource users. It may, after all, be better to invest in developing each dimension of adaptive capacity.

Future research might identify and test the significance of other influences on adaptive capacity, especially across other scales. For example, how people embedded within different institutional contexts are enhanced or restricted in their capacity by the higher capacity of the industry, region, and nation to support them will be important. It would also be key to evaluate the collective influence of individual adaptation responses on broader scale, i.e., industry, regional, or community, outcomes.

Managing for resilience is to accept uncertainty and be prepared for change (Holling 1996, Folke 2006, Nelson et al. 2007). A resilient society requires the capacity to cope and adapt to changes in the climate-sensitive resource base. As summarized by Olsson et al. (2004:75), "learning how to deal with uncertainty and adapt to changing conditions is becoming essential in a world where humanity plays a major role in shaping biospheric processes from genetic levels to global scales." To navigate the future, resource users will require the capacity to manage risk and uncertainty, be strategic, have flexibility to absorb the costs of change, and have an interest in adapting. Flexibility and an ability to improvise and switch strategies to meet changing conditions and maintain momentum will be essential (Geldenhuys 2004, Hahn et al. 2006, LaFlamme 2011). We see that strong collaborative networks, opportunities for formal and shared learning, and above all good leadership will set the industry in good stead. With this knowledge, industry leaders and resource managers may bring closer to reality the most fundamental of all human goals: to live in harmony with the environment.

Responses to this article can be read online at: http://www.ecologyandsociety.org/issues/responses. $\mathrm{php} / 6440$

\begin{abstract}
Acknowledgments:
The funding for this study was obtained from the Federal Department of Agriculture, Forestry and Fisheries (DAFF) and the Climate Adaptation Flagship, CSIRO. We are sincerely grateful to the 240 producers that agreed to participate in the study and to Amanda Elledge, Kate Nairn, Svetlana Ukolova, Charlie Morgan, and Jamie Atwell for their dedicated efforts and brilliant skills as interviewers. Sincere thanks also to John Gardner and Lilly Camacho for constructive comments on various drafts of the manuscript.
\end{abstract}

\section{LITERATURE CITED}

Adger, W. N., J. Barnett, K. Brown, N. A. Marshall, and K. O'Brien. 2013. Cultural dimensions of climate change impacts and adaptation. Nature Climate Change 3:112-117. http://dx.doi. org/10.1038/nclimate1666

Allison, H. E., and R. J. Hobbs. 2004. Resilience, adaptive capacity, and the "Lock-in Trap" of the Western Australian Agricultural Region. Ecology and Society 9(1): 3. [online] URL: http://www.ecologyandsociety.org/vol9/iss1/art3/

Anderies, J., M. Janssen, and B. Walker. 2002. Grazing management, resilience, and the dynamics of a fire-driven rangeland system. Ecosystems 5:23-44. http://dx.doi.org/10.1007/ s10021-001-0053-9

Ash, A., P. McIntosh, B. Cullen, P. Carberry, and M. S. Smith. 2007. Constraints and opportunities in applying seasonal climate forecasts in agriculture. Australian Journal of Agricultural Research 58:952-965. http://dx.doi.org/10.1071/AR06188

Bailey, C., and C. Pomeroy. 1996. Resource dependency and development options in coastal Southeast Asia. Society and Natural Resources 9:191-199. http://dx.doi.org/10.1080/08941929609380964

Barnes, T. J., R. Hayter, and E. Hay. 1999. "Too young to retire, too bloody old to work": forest industry restructuring and community response in Port Alberni, British Columbia. Forestry Chronicle 75:781-787. http://dx.doi.org/10.5558/tfc75781-5 
Berkhoff, K., and S. Herrmann. 2009. Modeling land use change: a GIS based modeling framework to support integrated land use planning (NabanFrame). Advances in GIscience 309-328. http:// dx.doi.org/10.1007/978-3-642-00318-9_16

Bowd, R., N. Quinn, D. C. Kotze, D. G. Hay, and M. Mander. 2012. The identification of potential resilient estuary-based enterprises to encourage economic empowerment in South Africa: a toolkit approach. Ecology and Society 17(3): 15. http:// dx.doi.org/10.5751/ES-04840-170315

Briske, D. D., R. A. Washington-Allen, C. R. Johnson, J. A. Lockwood, D. R. Lockwood, T. K. Stringham, and H. H. Shugart. 2010. Catastrophic thresholds: a synthesis of concepts, perspectives, and applications. Ecology and Society 15(3): 37. [online] URL: http://www.ecologyandsociety.org/vol15/iss3/ $\underline{\operatorname{art} 371}$

Brooks, N., and W. N. Adger. 2004. Assessing and enhancing adaptive capacity. Pages 165-181 in B. Lim and E. SpangerSiegfried, editors. Adaptation policy frameworks for climate change: developing strategies, policies and measures. Cambridge University Press, Cambridge, UK.

Brooks, N., W. Neil Adger, and P. Mick Kelly. 2005. The determinants of vulnerability and adaptive capacity at the national level and the implications for adaptation. Global Environmental Change 15:151-163. http://dx.doi.org/10.1016/j. gloenvcha.2004.12.006

Carpenter, S., B. Walker, J. M. Anderies, and N. Abel. 2001. From metaphor to measurement: resilience of what to what? Ecosystems 4:765-781. http://dx.doi.org/10.1007/s10021-001-0045-9

Carroll, M. S., and R. G. Lee. 1990. Occupational community and identity among Pacific North Western loggers: implications for adapting to economic changes. Pages 141-154 in R. G. Lee, D. R. Field, and W. R. J. Burch, editors. Community and forestry: continuities in the sociology of natural resources. Westview, Boulder, Colorado, USA.

Cinner, J., M. M. P. B. Fuentes, and H. Randriamahazo. 2009. Exploring social resilience in Madagascar's marine protected areas. Ecology and Society 14(1): 41. [online] URL: http://www. ecologyandsociety.org/vol14/iss1/art41/

Cinner, J. E., M. J. Marnane, and T. R. McClanahan. 2005. Conservation and community benefits from traditional coral reef management at Ahus Island, Papua New Guinea. Conservation Biology 19:1714-1723. http://dx.doi.org/10.1111/j.1523-1739.2005.00209. $\underline{\mathrm{x}-\mathrm{i} 1}$

Cinner J. E., and Ö. Bodin. 2010. Livelihood diversification in tropical coastal communities: a network-based approach to analyzing 'livelihood landscapes'. PLOS One 5(8). http://dx.doi. org/10.1371/journal.pone.0011999

Cinner, J. E., C. Folke, T. Daw, and C. C. Hicks. 2011. Responding to change: using scenarios to understand how socioeconomic factors may influence amplifying or dampening exploitation feedbacks among Tanzanian fishers. Global Environmental Change 21:7-12. http://dx.doi.org/10.1016/j.gloenvcha.2010.09.001

Cinner, J. E., T. R. McClanahan, N. A. J. Graham, T. M. Daw, J. Maina, S. M. Stead, A. Wamukota, K. Brown, and Ö. Bodin.
2012. Vulnerability of coastal communities to key impacts of climate change on coral reef fisheries. Global Environmental Change 22:12-20. http://dx.doi.org/10.1016/j.gloenvcha.2011.09.018

Cinner, J. E., S. G. Sutton, and T. G. Bond. 2007. Socioeconomic thresholds that affect use of customary fisheries management tools. Conservation Biology 21:1603-1611.

Claudet, J., S. Roussel, D. Pelletier, and H. Rey-Valette. 2006. Spatial management of inshore areas: theory and practice. Vie Et Milieu/Life and Environment 56:301-305.

Cobon, D. H., G. S. Stone, J. O. Carter, J. C. Scanlan, N. R. Toombs, X. Zhang, J. Willcocks, and G. M. McKeon. 2009. The climate change risk management matrix for the grazing industry of northern Australia. Rangeland Journal 31:31-49. http://dx.doi. org/10.1071/RJ08069

Cooper, P. J. M., J. Dimes, K. P. C. Rao, B. Shapiro, B. Shiferaw, and S. Twomlow. 2008. Coping better with current climatic variability in the rain-fed farming systems of sub-Saharan Africa: an essential first step in adapting to future climate change? Agriculture Ecosystems \& Environment 126:24-35. http://dx.doi. org/10.1016/j.agee.2008.01.007

Crimp, S. J., C. J. Stokes, S. M. Howden, A. D. Moore, B. Jacobs, P. R. Brown, A. J. Ash, P. Kokic, and P. B. Leith. 2010. Managing Murray-Darling Basin livestock systems in a variable and changing climate: challenges and opportunities. Rangeland Journal 32:293-304. http://dx.doi.org/10.1071/RJ10039

Cumming, G. S., D. M. Cumming, and C. L. Redman. 2006. Scale mismatches in social-ecological systems: causes, consequences, and solutions. Ecology and Society 11(1): 14. [online] URL: $\underline{\text { http:// }}$ www.ecologyandsociety.org/vol11/iss1/art14/

Dessai, S., and M. Hulme. 2007. Assessing the robustness of adaptation decisions to climate change uncertainties: a case study on water resources management in the east of England. Global Environmental Change 17:59-72. http://dx.doi.org/10.1016/j. gloenvcha.2006.11.005

Dougill, A. J., E. D. G. Fraser, and M. S. Reed. 2010. Anticipating vulnerability to climate change in dryland pastoral systems: using dynamic systems models for the Kalahari. Ecology and Society 15(2): 17. [online] URL: http://www.ecologyandsociety.org/ vol15/iss2/art17/

Flora, C. B., and J. L. Flora. 1993. Entrepreneurial social infrastructure: a necessary ingredient. Annals of the American Academy of Political and Social Science 529:48-58. http://dx.doi. org/10.1177/0002716293529001005

Flora, J. L. 1998. Social capital and communities of place. Rural Sociology 63:481-506. http://dx.doi.org/10.1111/j.1549-0831.1998. tb00689.x

Folke, C. 2006. Resilience: the emergence of a perspective for social-ecological systems analyses. Global Environmental Change 16:253-267. http://dx.doi.org/10.1016/j.gloenvcha.2006.04.002

Geldenhuys, C. J. 2004. Bark harvesting for traditional medicine: from illegal resource degradation to participatory management. Scandinavian Journal of Forest Research 19:103-115. http://dx. doi.org/10.1080/14004080410034182 
Granovetter, M. S. 1973. The strength of weak ties. American Journal of Sociology 78:1360-1381. http://dx.doi.org/10.1086/225469

Gross, J. E., R. R. J. McAllister, N. Abel, D. M. Stafford Smith, and Y. Maru. 2006. Australian rangelands as complex adaptive systems: a conceptual model and preliminary results. Environmental Modelling and Software 21:1264-1272. http://dx. doi.org/10.1016/j.envsoft.2005.04.024

Gunderson, L. 1999. Resilience, flexibility and adaptive management - antidotes for spurious certitude? Conservation Ecology 3(1): 7. [online] URL: http://www.ecologyandsociety.org/ vol3/iss1/art7/

Gunderson, L., C. Folke, M. Lee, and C. S. Holling. 2002. In memory of mavericks. Conservation Ecology 6(2): 19. [online] URL: http://www.ecologyandsociety.org/vol6/iss2/art19/

Gunderson, L., and C. S. Holling. 2002. Panarchy: understanding transformations in human and natural systems. Island, Washington, D.C., USA.

Hahn, T., P. Olsson, C. Folke, and K. Johansson. 2006. Trustbuilding, knowledge generation and organizational innovations: the role of a bridging organization for adaptive comanagement of a wetland landscape around Kristianstad, Sweden. Human Ecology 34:573-592. http://dx.doi.org/10.1007/s10745-006-9035$\underline{\mathrm{Z}}$

Hansen, J. W. 2002. Applying seasonal climate prediction to agricultural production. Agricultural Systems 74:305-307. http:// dx.doi.org/10.1016/S0308-521X(02)00042-2

Hobbs, N. T., K. A. Galvin, C. J. Stokes, J. M. Lackett, A. J. Ash, R. B. Boone, R. S. Reid, and P. K. Thornton. 2008. Fragmentation of rangelands: implications for humans, animals, and landscapes. Global Environmental Change 18:776-785. http://dx.doi. org/10.1016/j.gloenvcha.2008.07.011

Holling, C. S. 1996. Surprise for science, resilience for ecosystems, and incentives for people. Ecological Applications 6:733-735. http://dx.doi.org/10.2307/2269475

Howden, S. M., J.-T. Soussana, F. N. Tubiello, N. Chhetri, M. Dunlop, and H. Meinke. 2007. Adapting agriculture to climate change. Proceedings of the National Academy of Sciences 104:19691-19696. http://dx.doi.org/10.1073/pnas.0701890104

Howden, S. M., and C. J. Stokes, editors. 2010. Adapting agriculture to climate change. Preparing Australian agriculture, forestry and fisheries for the future. CSIRO, Collingwood, Australia.

International Panel on Climate Change (IPCC). 2007. Climate change 2007: the physical science basis. S. Solomon, D. Qin, M. Manning, Z. Chen, M. Marquis, K. B. Averyt, M. Tignor and H. L. Miller, editors. Contribution of Working Group I to the Fourth Assessment Report of the International Panel on Climate Change. Cambridge University Press, Cambridge, UK.

Joseph, C., T. I. Gunton, and J. C. Day. 2008. Implementation of resource management plans: identifying keys to success. Journal of Environmental Management 88:594-606. http://dx.doi. org/10.1016/j.jenvman.2007.03.028

Kates, R. W., W. C. Clark, R. Corell, M. Hall, C. C. Jaeger, I. Lowe, J. J. McCarthy, H. J. Schnellnhuber, B. Bolin, N. M.
Dickson, S. Faucheux, G. C. Gallopin, A. Greubler, B. Huntley, J. Jäger, N. S. Jodha, R. E. Kasperson, A. Mabogunje, P. Matson, H. A. Mooney, B. Moore III, T. Riordan, and U. Svedin. 2000. Sustainability Science. Discussion Paper 2000-33. Kennedy School of Government, Harvard University, Cambridge, Massachusetts, USA. http://dx.doi.org/10.2139/ssrn.257359

Keogh, D. U., I. W. Watson, K. L. Bell, D. H. Cobon, and S. C. Dutta. 2006. Climate information needs of Gascoyne-Murchison pastoralists: a representative study of the Western Australian grazing industry. Australian Journal of Experimental Agriculture 45:1613-25. http://dx.doi.org/10.1071/EA04275

LaFlamme, M. 2011. A framework for sustainable rangeland livelihoods. Rangeland Journal 33:339-351. http://dx.doi. org/10.1071/RJ11023

Levin, S., S. Barrett, S. Aniyar, W. Baumol, C. Bliss, B. Bolin, P. Dasgupta, P. R. Ehrich, C. Folke, I.-M. Gren, C. S. Holling, A. Jansson, B.-O. Jansson, K.-G. Mäler, D. Martin, C. Perrings, and E. Sheshinski. 1998. Resilience in natural and socioeconomic systems. Environment and Development Economics 3:222-235. http://dx.doi.org/10.1017/S1355770X98240125

Lewicka, M. 2011. Place attachment: how far have we come in the last 40 years? Journal of Environmental Psychology 31:207-230. http://dx.doi.org/10.1016/i.jenvp.2010.10.001

Likert, R. 1932. A technique for the measurement of attitude. Archives of Psychology 140:1-55.

Marshall, N. A. 2010. Understanding social resilience to climate variability in primary enterprises and industries. Global Environmental Change 20:36-43. http://dx.doi.org/10.1016/j. gloenvcha.2009.10.003

Marshall, N. A. 2011. Assessing resource dependency on the rangelands as a measure of climate sensitivity. Society \& Natural Resources 24:1105-1115. http://dx.doi.org/10.1080/08941920.2010.509856

Marshall, N. A., A.-M. Dowd, A. Fleming, C. Gambley, M. Howden, E. Jakku, C. Larsen, P. A. Marshall, K. Moon, S. Park, and P. J. Thorburn. 2014. Transformational capacity in Australian peanut farmers for better climate adaptation. Agronomy for Sustainable Development. http://dx.doi.org/10.1007/s13593-013-0186-1

Marshall, N. A., D. M. Fenton, P. A. Marshall, and S. Sutton. 2007. How resource dependency can influence social resilience within a primary resource industry. Rural Sociology 72:359-390.

Marshall, N. A., I. J. Gordon, and A. J. Ash. 2011. The reluctance of resource-users to adopt seasonal climate forecasts to enhance resilience to climate variability on the rangelands. Climatic Change 107:511-529. http://dx.doi.org/10.1007/s10584-010-9962y

Marshall, N. A., and P. A. Marshall. 2007. Conceptualizing and operationalizing social resilience within commercial fisheries in northern Australia. Ecology and Society 12(1): 1. [online] URL: http://www.ecologyandsociety.org/vol12/iss1/art1/

Marshall, N. A., S. E. Park, W. N. Adger, K. Brown, and S. M. Howden. 2012. Transformational capacity and the influence of place and identity. Environmental Research Letters 7:034022. http://dx.doi.org/10.1088/1748-9326/7/3/034022 
Marshall, N. A., and A. Smajgl. 2013. Understanding variability in adaptive capacity on rangelands. Rangeland Ecology and Management 66(1):88-94. http://dx.doi.org/10.2111/REM-D-11-00176.1

Marshall, N. A., C. J. Stokes, S. M. Howden, and R. N. Nelson. 2010. Enhancing adaptive capacity. Pages 245-256 in C. Stokes and S. M. Howden, editors. Adapting agriculture to climate change: preparing Australian agriculture, forestry and fisheries for the future. CSIRO Publishing, Canberra, Australia.

Marshall, N. A., R. C. Tobin, P. A. Marshall, M. Gooch, and A. Hobday. 2013. Social vulnerability of marine resource users to extreme weather events. Ecosystems 16:797-809. http://dx.doi. org/10.1007/s10021-013-9651-6

McAllister, R. R. J., N. Abel, C. J. Stokes, and I. J. Gordon. 2006. Australian pastoralists in time and space: the evolution of a complex adaptive system. Ecology and Society 11(2): 41. [online] URL: http://www.ecologyandsociety.org/vol11/iss2/art41/

McAllister, R. R. J., I. J. Gordon, and M. A. Janssen. 2005. Trust and cooperation in natural resource management: the case of agistment in rangelands. Pages 2334-2339 in Modsim 2005: International Congress on Modelling and Simulation: advances and applications for management and decision making. Modelling and Simulation Society of Australia and New Zealand, Melbourne, Australia.

McKeon, G. M., A. Ash, W. Hall, and M. Stafford Smith. 2000. Simulation of grazing strategies for beef production in north-east Queensland. Pages 227-252 in G. L. Hammer, N. Nicholls, and C. Mitchell, editors. Applications of seasonal climate forecasting in agricultural and natural ecosystems. Kluwell Academic, Dordrecht, The Netherlands. http://dx.doi.org/10.1007/978-94-$\underline{015-9351-9 \quad 15}$

McKeon, G. M., W. B. Hall, B. K. Henry, G. S. Stone, and I. W. Watson. 2004. Pasture degradation and recovery in Australia's rangelands: learning from history. Queensland Department of Natural Resources, Mines and Energy, Brisbane, Australia.

McPeak, J. G. 2003. Analyzing and addressing localized degradation in the commons. Land Economics 79:515-536. http:// dx.doi.org/10.2307/3147297

Mekbeb, E. T., R. J. Lilieholm, D. J. Blahna, and L. E. Kruger. 2009. Resource use, dependence and vulnerability: communityresource linkages on Alaska's Tongass National Forest. Ecosystems and Sustainable Development Vii 122:263-272. http:// dx.doi.org/10.2495/ECO090251

Nelson, D. R., W. N. Adger, and K. Brown. 2007. Adaptation to environmental change: contributions of a resilience framework. Annual Review of Environment and Resources 32:395-419. http:// dx.doi.org/10.1146/annurev.energy.32.051807.090348

Olsson, P., C. Folke, and F. Berkes. 2004. Adaptive comanagement for building resilience in social-ecological systems. Environmental Management 34:75-90. http://dx.doi.org/10.1007/s00267-003-0101-7

Ostry, A. 1999. The links between industrial, community, and ecological sustainability: a forestry case study. Ecosystem Health 5:193-203. http://dx.doi.org/10.1046/j.1526-0992.1999.09930.x

Park, S. E., N. A. Marshall, E. Jakku, A. M. Dowd, S. M. Howden, E. Mendham, and A. Fleming. 2012. Informing adaptation responses to climate change through theories of transformation. Global Environmental Change 22:115-126. http://dx.doi. org/10.1016/j.gloenvcha.2011.10.003

Pelling, M. 2007. Learning from others: the scope and challenges for participatory disaster risk assessment. Disasters 31:373-385. http://dx.doi.org/10.1111/j.1467-7717.2007.01014.x

Penaloza Acosta, M., F. Arevalo Cohen, and D. S. Roberto. 2009. Impact of technological management on the environment. Revista De Ciencias Sociales 15:306-316.

Price, L., and N. Evans. 2009. From stress to distress: conceptualizing the British family farming patriarchal way of life. Journal of Rural Studies 25:1-11. http://dx.doi.org/10.1016/j. jrurstud.2008.03.008

Quinn, C. H., G. Ziervogel, A. Taylor, T. Takama, and F. Thomalla. 2011. Coping with multiple stresses in rural South Africa. Ecology and Society 16(3): 2. http://dx.doi.org/10.5751/ ES-04216-160302

Reed, M. S., A. J. Dougill, and M. J. Taylor. 2007. Integrating local and scientific knowledge for adaptation to land degradation: Kalahari rangeland management options. Land Degradation \& Development 18:249-268. http://dx.doi.org/10.1002/ldr.777

Riebsame, W. E. 1988. Assessing the social implications of climate fluctuations: a guide to climate impact studies. United Nations Environment Programme, Nairobi, Kenya.

Shirk, J. L., H. L. Ballard, C. C. Wilderman, T. Phillips, A. Wiggins, R. Jordan, E. McCallie, M. Minarchek, B. V. Lewenstein, M. E. Krasny, and R. Bonney. 2012. Public participation in scientific research: a framework for deliberate design. Ecology and Society 17(2): 29. http://dx.doi.org/10.5751/ ES-04705-170229

Smit, B., and J. Wandel. 2006. Adaptation, adaptive capacity and vulnerability. Global Environmental Change 16:282-292 http://dx. doi.org/10.1016/j.gloenvcha.2006.03.008

Smithers, J., and B. Smit. 1997. Human adaptation to climatic variability and change. Global Environmental Change 7:129-146. http://dx.doi.org/10.1016/S0959-3780(97)00003-4

Stafford Smith, D. M. 2008. The 'desert syndrome' - casuallylinked factors that characterise outback Australia. Rangeland Journal 30:3-14. http://dx.doi.org/10.1071/RJ07063

Stafford Smith, D. M., G. M. McKeon, I. W. Watson, B. K. Henry, G. S. Stone, W. B. Hall, and S. M. Howden. 2007. Learning from episodes of degradation and recovery in variable Australian rangelands. Proceedings of the National Academy of Sciences 104:20690-20695. http://dx.doi.org/10.1073/pnas.0704837104

Stokes, C. J., and S. M. Howden. 2010. Adapting agriculture to climate change: preparing Australian agriculture, forestry and fisheries for the future. CSIRO Publishing, Canberra, Australia.

Sutton, S. G., and R. C. Tobin. 2012. Social resilience and commercial fishers' responses to management changes in the Great Barrier Reef Marine Park. Ecology and Society 17(3): 6. http://dx.doi.org/10.5751/ES-04966-170306

Taljaard, S., J. H. Slinger, and J. H. Van Der Merwe. 2011. Criteria for evaluating the design of implementation models for integrated 
coastal management. Coastal Management 39:628-655. http://dx. doi.org/10.1080/08920753.2011.616670

Thomas, R. J. 2008. Opportunities to reduce the vulnerability of dryland farmers in Central and West Asia and North Africa to climate change. Agriculture Ecosystems \& Environment 126:36-45. http://dx.doi.org/10.1016/j.agee.2008.01.011

Tompkins, E. L., M. C. Lemos, and E. Boyd. 2008. A less disastrous disaster: managing response to climate-driven hazards in the Cayman Islands and NE Brazil. Global Environmental Change 18:736-745. http://dx.doi.org/10.1016/j.gloenvcha.2008.07.010

Tucker, C. M., H. Eakin, and E. J. Castellanos. 2010. Perceptions of risk and adaptation: coffee producers, market shocks, and extreme weather in Central America and Mexico. Global Environmental Change 20:23-32. http://dx.doi.org/10.1016/j. gloenvcha.2009.07.006

Walker, B., S. Carpenter, J. Anderies, N. Abel, G. S. Cumming, M. Janssen, L. Lebel, J. Norberg, G. D. Peterson, and R. Pritchard. 2002. Resilience management in social-ecological systems: a working hypothesis for a participatory approach. Conservation Ecology 6(1): 14. [online] URL: http://www. ecologyandsociety.org/vol6/iss1/art14/

Walker, B., L. Gunderson, A. Kinzig, C. Folke, S. Carpenter, and L. Schultz. 2006. A handful of heuristics and some propositions for understanding resilience in social-ecological systems. Ecology and Society 11(1): 13 [online] URL: http://www.ecologyandsociety. org/vol11/iss1/art13/

Walker, B. H., and M. A. Janssen. 2002. Rangelands, pastoralists and governments: interlinked systems of people and nature. Philosophical Transactions of the Royal Society of London Series B-Biological Sciences 357:719-725. http://dx.doi.org/10.1098/ rstb.2001.0984 